\title{
Assessment of the Readiness and Resilience of Czech Society against Water-Related Crises
}

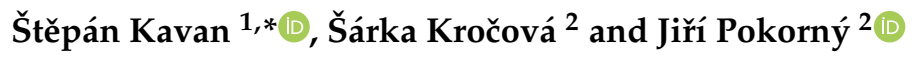 \\ 1 Faculty of Health and Social Studies, University of South Bohemia in Ceske Budejovice, \\ 37011 Ceske Budejovice, Czech Republic \\ 2 Faculty of Safety Engineering, VSB-Technical University of Ostrava, 70030 Ostrava, Czech Republic; \\ sarka.krocova@vsb.cz (S.K.); jiri.pokorny@vsb.cz (J.P.) \\ * Correspondence: stepan.kavan@email.cz
}

Citation: Kavan, Š.; Kročová, Š.; Pokorný, J. Assessment of the Readiness and Resilience of Czech Society against Water-Related Crises. Hydrology 2021, 8, 14. https:// doi.org/10.3390/hydrology 8010014

Academic Editors: Tamim Younos,

Tammy Parece, Juneseok Lee, Jason Giovannettone and Alaina J. Armel

Received: 9 December 2020

Accepted: 21 January 2021

Published: 22 January 2021

Publisher's Note: MDPI stays neutral with regard to jurisdictional claims in published maps and institutional affiliations.

Copyright: (c) 2021 by the authors. Licensee MDPI, Basel, Switzerland. This article is an open access article distributed under the terms and conditions of the Creative Commons Attribution (CC BY) license (https:/ / creativecommons.org/licenses/by/ $4.0 /)$.

\begin{abstract}
This assessment of societal readiness and resilience to water-related situations in the Czech Republic focuses on an interdisciplinary approach in the Czech Republic for solving this problem. The goal of the article is to evaluate and characterize the preparedness for handling water-related crises. The analysis is carried out via a SWOT analysis, which is a universal analytical method used to understand and interpret strengths and weaknesses and to identify opportunities and threats. For the calculation of the weight factor of the SWOT analysis, an assessment was determined based on the multicriteria analysis. The pair comparison method was used to determine the relative importance of the parameters of the strengths and weaknesses, opportunities and threats. The Fuller Triangle method was chosen for the system used to make the comparisons of the individual criteria. The uniqueness of the study consists of the issue of water management, which is thus reflected from a non-traditional perspective, being a contemporary model-the paradigm of the view on the preparedness of the planning documentation as one of the characteristics of societal resilience for water-related crises. The result of the research is the fact that a positive approach prevails in the researched area from the perspective of preparedness for water-related crises. For the creation of the conditions, the factors arising from the internal environment currently prevail slightly over those arising from the external environment.
\end{abstract}

Keywords: society; risk analysis; water-related crises; resilience; security; floods; drinking water; crisis planning

\section{Introduction}

Water has many facets. In general, water is often characterized as one of the basic components required for life. A second viewpoint is that water is a natural element which threatens human society via floods. Human activities have significantly interfered with the environment and in doing so have altered the behavior of surface as well as underground water in the landscape. Water is thus becoming an increasingly precious liquid and simultaneously a feared element. In order to protect the values it has built up, society strives to adopt measures with the aim of preventing or minimizing risks. Water management in the area of drinking water and protection against its negative aspects are some of the important activities carried out by a dynamically developing society on the level of communities and countries, and also on an international level.

The information obtained provides an assessment of water-related crises for which a type plan has been prepared based on a risk analysis within crisis management. The water management area is thus reflected on from a non-traditional perspective and a contemporary model - the paradigm of considering societal resilience for water-related crises. The assessment was carried out within the scope of a case study focusing on the Czech Republic. In this aspect, the presented study is unique, innovative and original by incorporating and combining a reflection on crisis management and on water-related crises. 
International literature in the area usually offers reflections of specific separate components, which can be classified into texts focusing on securing drinking water, handling floods and crisis management. The topic of the emergency supply of drinking water is handled, for instance, from the viewpoint of a strategy for the supply of drinking water, the area of water management systems and the associated operating risks [1], the possible use of underground water for emergency supply and an assessment of the sources of backup drinking water sources [2,3], Preventing Secondary Disasters through Providing Emergency Water Supply [4]; yet another approach is the analysis of risks and sensitivity of potential sources of the emergency water supply [5], emergency supply of drinking water with the use of available technology [6]. One important document with an international impact in this area is "Water Safety Plans", authored by the World Health Organisation; the document focuses on Managing drinking-water quality from catchment to consumer [7].

The second area that has been the focus for researchers is that of floods. There is an ample number of documents and papers; however, these are very diverse in nature, covering topics such as various means of protecting against floods [8-10], the framework for flood risk communication [11,12], strategies for reducing risks during floods [13-16], and the implementation of the flood risk management directive in selected European countries $[17,18]$. Some documents also focus on selected aspects of floods such as the use of mobile Mose barriers to protect Venice [19] or the household insurance system for households located in areas at risk from floods [20].

One specific area which is also covered by the presented study and is often reflected on separately in the literature is the area of crisis management. The management of people and crises represents an important component of the study. Crisis management must be based on a risk analysis and react to potential threats [21]. International studies usually focus on a single topic, such as the government's position on crisis management [22], team-based handling of catastrophes [23], coordination and collaboration when handling floods [24] and the sustainability of critical infrastructure [25]. A link between crisis management and water-related catastrophes in the scope covered by this article cannot be found in international databases. This specific angle thus provides a new perspective on the given area and contributes to the development of crisis management theory. It will certainly be interesting to carry out a similar study in other countries and to compare the results obtained for this specific area of safety within the scope of further systemic research.

In the Czech Republic, as a country situated in Central Europe with a predominantly continental climate and without access to a sea, the experience with the solution of waterrelated crises is primarily connected with the extensive floods in 1997 and 2002. These floods first hit the eastern part of the country (1997) and subsequently the center and west of the country (2002). From the perspective of the supply of drinking water, no wide-reaching problems with a lack of water have occurred. In recent years, however, with regard to lower rainfall and a decrease in the level of groundwater, there were local problems with the supply of drinking water and also partially with a restriction on the use of surface water for irrigation. The given facts were reflected in the area of crisis management when preparing risk analyses and were also exhibited during the processing of type plans as part of the crisis plans.

Society strongly emphasizes the prevention of extraordinary events [26-28]. Understanding the risks and threats has a direct impact on the stance of the public administration and consequently also the general populace to planned or adopted measures and the associated economic costs. The selection of topics for this study was based on the risks that were identified and evaluated in the "Risk Analysis for the Czech Republic" and approved by the Czech government's ruling of 27 April 2016 after discussion in the Country's Security Council [29].

A total of 72 types of hazards were identified in the Risk Analysis for the Czech Republic, divided into three basic categories [29]. These are: 
- Acceptable risks, no extraordinary measures are expected, these are usually situations that can be handled in the scope of standard activities of integrated emergency services and the appropriate administrative bodies;

- Conditionally acceptable risks, which require the adoption of measures aimed at their elimination; these occur in the areas of preparing for extraordinary events and include notably emergency planning and the preparation of the integrated emergency system and its components;

- Unacceptable risks, where the measures aimed at their elimination are part of the preparation for the handling of crises and notably include crisis planning.

The risk analysis identified 22 types of hazards/risks that were evaluated as unacceptable and where, if they occur, these are expected to lead to a state of crisis and need to be prioritized. Risks that are unacceptable for society include (in the category of antropogeneous and natural risks, the subcategory of abiotic and technogeneous risks): floods, flash floods, catastrophic rainfall, disruption of dams of prominent waterworks (special floods), and large-scale disruptions of the delivery of drinking water. When preparing the study, the authors decided to adopt a certain level of generality and focus the article on events whose theme is associated with water, with the aim of increasing the awareness of and subsequently improving the quality of prevention within these risk categories (see also Czech government directive 369/2016).

In connection with the risk analysis for the purpose of system access, it is important to formulate the perception of safety and to specify deviations from safety and disruptions of safety, i.e., defining various types of events. Safety and security are not stand-alone constructs without relations to other notions - they are always considered with respect to a referential object [30]. The referential object may be a country, company, community, person, building, secret information, etc. It is then possible to speak about the safety and security of a country, information security, etc. The safety and security environment consists of a range of elements of the referential object, which are then linked to other elements [31]. This work focuses on country-level safety and security in relation to critical situations related to water.

In terms of safety, the actual safety environment consists of real and usually wellknown referential objects, such as a country, its organizational elements, or international organizations. Safety then represents a state of calmness, where the referential object is not experiencing interference and is not under threat, and hence it is not necessary to make proactive steps to ensure the required state. A joint foundation for all areas dealing with safety is the adoption of a set of measures aimed at ensuring safety. These measures are aimed at reaching a state where damage is minimized and the referential object can continue performing its intended function [32]. The measures aimed at handling crises that have been prepared for the Czech Republic are handled within the crisis management and planning system.

Planning is one of the basic functions of management. Crisis planning in the Czech Republic is a crisis management tool that represents a summary of planning activities, procedures and links implemented by crisis management bodies and their designated government or public institutions, legal bodies or entrepreneurs in order to implement the goals and tasks associated with ensuring the safety of the country and its populace during emergencies [33].

Humans live in a society that consists of various people who all have their own interests, capabilities and preferences. That is why it is necessary to regulate our mutual cohabitation, for instance via legal regulations, and during crises this system also incorporates measures that arise from the crisis plan. In the case of water crisis management, the crisis plan focuses on risks which were assessed as unacceptable risks. These groups include catastrophes caused by floods, flash floods, excessive rainfall, breaches of dams of significant waterworks (special floods) and significant disruptions of drinking water supply. 
The aim of the article is to assess and characterize crisis situations related to water, for a type plan that has been prepared within crisis planning based on a risk analysis. The assessment of this topic is carried out primarily from the viewpoint of prepared measures targeting society and individuals. The assessment is implemented as a case study under the conditions of the Czech Republic. From a scientific viewpoint, this represents a research limitation and means that we focus on the conditions and approach to the given topic implemented by the specific considered country. In view of the aims of the study, an assessment of the technical quality of specific equipment of emergency services and of preventive technical-structural measures is not part of the study's scope. A certain limitation on the study comes from the composition of the expert group for performing the multicriteria analysis. Their own experience from the resolution of crisis situations (especially water-related) could influence the objectivity and a certain degree of detachment. For this reason, the expert group was comprised of experts from different areas. The essential characteristics were included as part of the performed SWOT analysis; in light of the scope of the study, it was not possible to resolve the individual type plans individually, but a summary evaluation of the plans that relate to water-related catastrophes was performed.

The theoretical part of the article delimits and characterizes selected type plans which are included in crisis plans and which are related to water. The practical part of the article focuses on a concretization of selected measures within type plans and possible impacts on life in the Czech Republic. The article assesses crisis preparedness within the scope of a case study focusing on the national level.

The research question was formulated as the process of creating organized knowledge based on systematic research. Specifically, the following research questions were formulated: how has the preparedness for crisis situations associated with water been incorporated in the planning documentation on the national level within the Czech Republic? How are individual type plans handling water-related catastrophes designed? An analysis of the topic was carried out in order to reflect these scientific problems.

\section{Materials and Methods}

\subsection{Methods}

The input information used to study the topic was obtained primarily via literature research, from provided internal sources of selected crisis management entities, and the activities of one of the authors as the group leader for preparing the Crisis Plan of the SouthBohemian Region. The practical part uses multicriteria analysis methods. Synthesis was used to connect the individual partial findings. The actual assessment of the preparedness (readiness) for crisis situations related to water listed in the planning documentation on the national level of the Czech Republic and the assessment of individual type plans handling catastrophes associated with water was carried out via a SWOT analysis.

The SWOT analysis (of Strengths, Weaknesses, Opportunities and Threats) was developed in the second half of the 20th century in the United States. It is a useful and highly universal analytical technique that provides us with an understanding and interpretation of strengths and weaknesses as well as of opportunities and threats. It is most frequently used in the area of business, as a strategic tool that can be used to help a company's development [34,35].

A SWOT analysis is based on an evaluation and analysis of the current state of the evaluated entity/topic, its internal environment and the current situation surrounding the assessed entity and outside environment. At its core, it identifies the strengths and weaknesses in the internal environment, meaning what the given entity is good at and where its weaknesses lie, and also analyzes the threats and opportunities located in the outside environment-i.e., factors which the entity itself cannot influence [36,37]. It begins by analyzing strengths, since these are considered an internal force. Above-standard skills, knowledge, and potentials are identified along with resources that may be used in the future to benefit the entity. Weaknesses represent an opposite of the strengths and notably 
include internal weaknesses of the organization/considered area, areas where it would be possible to achieve better results. Opportunities are used to identify potential options that may lead to improvement if they are correctly used. External circumstances were identified that may lead to future success. Threats then represent external influences that may make it more difficult to achieve the intended goals. Threats are used to identify aspects that bring negatives, factors which need to be taken into account and systematically prevented.

In order to determine the weight factor, it was necessary to identify the items of assessment. The assessment was carried out based on multicriteria decision-making. Decision-making here refers to choosing or classifying a value of one variant based on selected criteria. Decision-making leads to conflicts of interest, where in socially-economic systems it is difficult to identify priority values. Different groups of people give preference to different consequences of a decision, and hence the assessment of an optimal decision may be carried out via different criteria. The following criteria were selected to assess the individual properties of the SWOT analysis: societal impact, impact on health and lives of the population, economic regression, environmental impact and traffic limitations. A multicriteria evaluation was carried out by a group of experts from the Regional Office of the South-Bohemian Region-Crisis Management Department, the Czech Firefighting Services-Civil Protection Department, the Czech Police, Emergency Medical Services of the South Bohemian Region, Czech Army, Czech Hydrometeorological Institute, Povodí Vltavy and VSB - Technical University of Ostrava.

The pair comparison method was used to determine the relative importance of the parameters of the strengths and weaknesses, opportunities and threats. The individual criteria were compared with each other when calculating the weight coefficient. The more important criterion for the given problem was chosen from each pair. The Fuller Triangle method was chosen for the system used to make the comparisons. The research design scheme can be summarized in the following steps:

- $\quad$ specification of research goals and their limits;

- determination of water-related crises for which a type plan has been prepared in crisis planning on the basis of a risk analysis;

- SWOT analysis-specification of concrete criteria for individual areas;

- $\quad$ performance of multicriteria analysis-determination of concrete criteria values (score);

- Specification of relative importance of the parameters of individual characteristics and SWOT areas using the Fuller Triangle method (weight factor);

- calculation of criterion strength-product of score and weight factor;

- comparison of criterion strength for the individual SWOT areas (specification of partial sums);

- $\quad$ summary comparison and assessment of positive or negative approach;

- discussion and interpretation of results.

\subsection{Materials - Characteristics of Selected Type Plans}

\subsubsection{Type Plan-Large-Scale Disruptions of the Supply of Drinking Water}

A large-scale disruption of the supply of drinking water is a critical situation which is unlikely to occur unexpectedly, without a preceding event. If the cause of the disruption is simply a standard defect of the water supply network, its delivery can be secured by the appropriate operator of the water mains via a backup supply. However, if there is a critical situation that has a large-scale impact on society related to a large-scale interruption of the delivery of drinking water (where it will not be possible to secure a sufficient reserve supply), the supply of drinking water will be handled within the scope of the system for the emergency drinking water supply. The emergency drinking water supply here refers to securing drinking water for the population in the amount necessary to ensure survival, for the period necessary to restore the standard drinking water supply systems within the affected area.

Disruptions of the drinking water supply could be caused by contamination of the water source (intentional or unintentional), damage to the water treatment system used 
to create drinking water, extensive disruptions of the water network, or long periods of drought leading to a lack of underground as well as above-ground water. The possible impacts on society include: threats to the life and health of citizens due to drinking contaminated drinking water or water from other, unverified sources; lack of hygiene; the occurrence of epidemics of mass illnesses; intentional damage to water containers or other drinking water dispensing machinery in the case of potential panic or unrest; looting at drinking water retailers and others.

\subsubsection{Type Plan-Flood}

Floods mean a temporary significant increase in the level of water in rivers or other surface water bodies which causes the water to flood an area outside of the riverbed and may cause damage. Due to its significant amount of broken terrain, the Czech Republic has a very dense hydrographic network spanning a total of about 85 thousand kilometers. It is located in the temperate climate zone with a regular seasonal temperature and precipitation cycle. Aside from these long-term swings, short-term temperature changes are caused by frequent transitions of atmospheric fronts, which separate colder and warmer air and are often accompanied with rainfall.

In general, the long-term amount of rainfall increases at higher altitudes, but the predominant wind direction in mountainous areas is a significant factor as well. The average annual volume of outflow from the territory of the Czech Republic is about 15.1 billion $\mathrm{m}^{3}$, corresponding to a nominal outflow of $6.1 \mathrm{~L} \cdot \mathrm{s}^{-1} \cdot \mathrm{km}^{-2}$. The outflow ratios are, however, not equally distributed. The ratio between the average and maximum flow during a 100-year flood is 1:20 to 1:50 on larger rivers, may reach nearly 1:100 on smaller rivers, and small mountainous rivers may have even larger ratios. In the vast majority of cases, floods in the Czech Republic are decisively influenced by hydrological causes and phenomena that also occur in the Czech Republic. Floods coming from abroad may only be considered on the river of Ohra (flow into the Skalka reservoir), Lužnice (flow into the Třeboň pond system), Dyje (flow into the Vranov reservoir) and Stěnava (flow from Poland).

The floods caused by long-lasting regional rain $(1997,2002)$ caused the rise of floods on a large scape on a regional level. They usually occur on all watercourses in the afflicted region and propagate on medium-sized and larger watercourses (e.g., the Berounka, Vltava, Elbe, Morava, Thaya river basins).

Extreme winter and spring floods are caused by the melting of the snow cover, especially in combination with heavy rains. It can affect both mountain regions, where they happen most often at the end of the winter season, when intensive rains fall on the remains of snow cover, then primarily in foothills and middle elevations, but also in lowlands (Znojmo region 2006). In the second aforementioned case, the negative factors for the rise of significant flooding are, in particular: a large amount of snow cover in lower and middle elevations that can thaw over the course of a few short days; rainfall; the temperature of the air exceeding $8{ }^{\circ} \mathrm{C}$ on average and even persisting in the night on a level of about $4{ }^{\circ} \mathrm{C}$ and more; freezing soil under the snow cover, which limits the permeation and speeds up the runoff; and the strong convection increasing rainfall on the windward side and the increasing melting of snow.

Melting significant enough for a flood to arise can occur practically from the end of November until April. In a year with an abundance of snow, approximately 5 billion $\mathrm{m}^{3}$ of water accumulates in snow throughout the entire territory. The height of the snow cover reaches an average of $10-20 \mathrm{~cm}$ in the lowlands, $40-60 \mathrm{~cm}$ in middle elevations and more than $100 \mathrm{~cm}$ in the mountains. The period of the melting of the snow cover is not regular, over the long-term, the maximum average snow cover in lowlands is in the middle of February, in mountains in the second half of March. The risk of flooding from spring thaws has decreased when compared to the period of the first half of the 19th century as a result of warming, the regularity of spring flooding has decreased, though the threat of significant spring flooding remains. 
Flooding caused by ice phenomena occur even at relatively lower flow rates in sections of the flow susceptible to the creation of ice sheets and ice jams in sites with lower flow rates or in a narrow section of the riverbed (dangerous ice phenomena can arise on various flows and tend to occur very often on, for example, the rivers Berounka, Otava, Bečva, Moravská Sázava, Sázava, Divoká Orlice, etc.).

A critical situation may be announced if the ongoing critical water or flow levels and their impacts threaten the operation of critical infrastructure and where the handling of such situations is beyond the capabilities of individual regions in view of unfavorable weather forecasts. The impacts of large floods may include significant material damage and may have a long-term impact on the affected territory, and the impacts may require the use of all the country's available resources including the possible use of international humanitarian aid even beyond the duration of the flood itself.

\subsubsection{Type Plan-Flash Flood}

Flash floods are most frequently caused by sudden surface flow caused by significant and concentrated rainfall, which quickly concentrates in the river network due to broken terrain.

Flash floods are characterized by high rainfall over a shorter duration, i.e., a high intensity and limited areal extent. In general, potentially dangerous precipitation is usually connected to the transition of frontal disorders or the influx of warm and humid air, which supports the development of convective clouds. The probability of the occurrence of heavy precipitation increases in mountain ranges, which create conditions for the occurrence of extreme rainfall on windward sides thanks to the increased flow of air. The resulting flood flows are, in addition to the intensity and duration of the causal rain and size of the afflicted area, also dependent on the physical/geographical characteristics of the afflicted territory. The main factors here represent the size and shape of the river basin, the inclination ratios of the terrain, soil permeability and saturation of the river basin prior to the rainfall. In some cases of flood situations of a regional nature, which are caused by long-lasting, less heavy precipitation, there is a considerable worsening of the course of the flood in the afflicted territory by locally limited heavy rainfall. Flash floods can be expected more in rural areas.

Damage caused by excessive rainfall in rural areas including the erosion of agricultural areas and subsequent transport of sediments into built-up areas are, for the purposes of preparing type plans, considered to be a part of flash floods. The course of a flood is characterized by the type of the flood itself, the value of the culmination flow, the shape and volume of the flood wave and the season of its occurrence.

Summer flash floods caused by short but intense rains usually affect a small area. They may affect any smaller river, but have catastrophic consequences especially when affecting sloping fan-like rivers. They exhibit a very rapid rise in water levels, followed by a very quick decrease. In addition to high precipitation intensity, an important role is also played by the ability of the soil to hold/soak rainfall water, which is affected by vegetation and anti-erosion measures as well as the current saturation of the soil due to previous precipitation. The most dynamic onset and largest death tolls are usually caused by rivers that are approximately 1-20 $\mathrm{km}^{2}$ large, with a concentration period of less than $1 \mathrm{~h}$.

The risk factors for flash floods are:

- intensity of rain;

- $\quad$ speed of storm movement—-the slower the movement, the greater the risk;

- chain effect - the transition of several storms in rapid succession over one river basin; these storms do not need to be extremely strong;

- $\quad$ synergy of the movement of storms in the direction of the water flow in the river basin; if the storm moves in the direction of the water runoff from the river basin, the risk of flooding is higher than movement in the opposite direction;

- $\quad$ occurrence of impermeable and poorly permeable surfaces or the great previous saturation of the area supporting rapid runoff; 
- $\quad$ configuration of the terrain with steep slopes, narrow river valleys.

The possibility of predicting flash floods is very limited due to the sharp dynamic of the development of convective clouds from which heavy precipitation comes. Even if meteorological conditions for the occurrence of heavy precipitation can be forecast relatively successfully, the precise localization of the occurrence, the duration and intensity of the heavy precipitation, and thus the specific threat to a locality can essentially not be predicted.

The societal impacts may include:

- $\quad$ significant limitations of social services and securities of citizens evacuated from flooded areas and other citizens in the immediate vicinity of flooded areas;

- damage or destruction of houses and apartments, which will remain uninhabitable for a long period of time, long-term emergency accommodation of evacuated citizens;

- $\quad$ impact on the function of waste water treatment plants;

- damage to cultural landmarks;

- traffic restrictions caused by flooded roads, direct damage to roads and associated buildings (notably bridges and floodgates), landslides or power outages. In case of rail transport, damage to, e.g., rails, sidings, tractional rail or obstacles is expected, and this may also lead to traffic disruptions.

\subsubsection{Type Plan-Excessive Precipitation (Rainfall)}

For the purposes of crisis planning, excessive precipitation and its consequences refer to: the occurrence of intense precipitation in rural areas, leading to exceeding the capacity of the outflow network, flooding of lower floors of buildings and technical infrastructure by outflowing water. Damage caused by sudden excessive precipitation in rural areas including the erosion of agricultural areas and the subsequent transport of sediments into built-up areas is considered to be part of the flash flood or flood.

In unfavorable conditions, rainfall may lead to a quick build-up of flowing water, especially on reinforced, less permeable or saturated surfaces, and to the flooding of lowerplaced areas, buildings or underground areas, or to a rise of the water level in rivers and subsequent flooding. Excessive precipitation connected with storms is a fairly common phenomenon in the summer, but in most cases lasts only a short time (up to $30 \mathrm{~min}$ ). However, in some cases storm cells may remain exceptionally active and emit an extreme amount of precipitation over a very short period of time. Moreover, storm cells may agglomerate into a group of cells which repeatedly pass over the affected area. In addition to flash floods, storms are also usually accompanied with sudden gusts of wind, electric discharges, and possibly hailstorms.

The occurrence of excessive precipitation is very random, and so it is very difficult to forecast the specific affected areas. They may also cause other unfavorable phenomena, notably soil erosion and landslides, which may then also damage traffic infrastructure, clog sewage systems, reduce flow capacities of river beds and the retention area of water recipients.

\subsubsection{Type Plan—Disruptions of Dams of Significant Waterworks Associated with a Special Flood}

This category covers floods caused by artificial factors, which are situations that may occur on certain kinds of water works. The owners (users) or managers of water works are obliged to ensure that these are supervised by specialized technical and safety officers with the aim of continuously tracking the technical condition of the water works in view of its stability, safety and possible disruptions along with the proposal of suitable corrective measures.

A special flood needs to be distinguished from natural floods, notably due to the different characteristics of its occurrence, course and the different flood measures that are to be used before and during a special flood. The handling of a special flood requires the careful preparation of bodies involved in the management of floods and crises and the preparation of a basic planning document (plan for protecting the landscape below a 
selected water facility against a special flood) aimed at handling arising critical situations. This critical situation can only be forecasted in the case of an unmanageable waterworks defect, gradually increasing overflow or water inflow into the waterworks following after long-lasting and/or sudden precipitation.

Disruption of a water work (dam) and adjacent buildings due to accumulated surface water associated with the occurrence of a flood wave via a special flood will, due to its extensive destructive effects, be a reason for the announcement of a critical situation and subsequent declaration of an emergency/crisis. The area where the emergency will be announced directly depends not only on the amount of held water, the landscape configuration below the waterworks and the characteristics of the flood wave, but also on the size of the cities and towns (in terms of residential zones and production facilities) that may be affected by the special flood. There will be immense loss of human life, health, property and infrastructure, but the precise scope of these will, to a significant extent, depend on how well prepared the local bodies and citizens are for this critical situation.

Table 1 contains an overview of the plan characteristics, the application scale and the societal impacts

Table 1. Overview of the plan characteristics.

\begin{tabular}{|c|c|c|}
\hline Type Plan & $\begin{array}{l}\text { Application Scale (Urban } \\
\text { or Rural) }\end{array}$ & Societal Impacts \\
\hline $\begin{array}{l}\text { Large-scale disruptions of } \\
\text { the supply of } \\
\text { drinking water }\end{array}$ & urban or rural & $\begin{array}{l}\text { threats to the life and health of citizens due to drinking contaminated } \\
\text { drinking water or water from other unverified sources; lack of hygiene; } \\
\text { occurrence of epidemics of mass illnesses; intentional damage to water } \\
\text { containers or other drinking water dispensing machinery in case of a } \\
\text { potential panic or unrest; looting at drinking water retailers }\end{array}$ \\
\hline Flood & urban or rural & $\begin{array}{l}\text { significant material damage and may have a long-term impact on the } \\
\text { affected territory, and the impacts may require the use of all the } \\
\text { country's available resources, including the possible use of } \\
\text { international humanitarian aid even beyond the duration of the } \\
\text { flood itself. }\end{array}$ \\
\hline Flash flood & rural & $\begin{array}{l}\text { limitations of social services and securities of citizens evacuated from } \\
\text { flooded areas; damage or destruction of houses and apartments; impact } \\
\text { on the function of waste water treatment plants, damage to cultural } \\
\text { landmarks; traffic restrictions caused by flooded roads, direct damage } \\
\text { to roads and associated buildings (notably bridges and floodgates), } \\
\text { landslides or power outages }\end{array}$ \\
\hline $\begin{array}{l}\text { Excessive precipitation } \\
\text { (rainfall) }\end{array}$ & urban & $\begin{array}{c}\text { may also cause other unfavorable phenomena, notably soil erosion and } \\
\text { landslides, which may then also damage traffic infrastructure, clog } \\
\text { sewage systems, reduce flow capacities of river beds and the retention } \\
\text { area of water recipients. }\end{array}$ \\
\hline
\end{tabular}

Disruptions of dams of
significant waterworks
associated with a
special flood

immense loss of human life, health, property and infrastructure, but the precise scope of these will, to a significant extent, depend on how well prepared the local bodies and citizens are for this critical situation.

Source: own research.

\section{Results}

\subsection{Factors of SWOT Analysis}

SWOT analysis was used to perform the actual assessment. In order to make the organization of the factors into individual segments of the analysis easier to read, we provide Table 2 of preparedness for water-related critical situations listed in crisis documentation and focusing on type plans. The table is divided into four quadrants: the left side contains factors that have a positive impact on the topic while the right side contains negative effects and undesirable factors. The upper part maps internal factors, while the lower part presents external influences. Individual factors of the analysis were processed based on 
multi-criteria analysis by a group of experts in the area of crisis management, planning and risk analysis.

Table 2. SWOT analysis of preparedness for water-related crises listed in the planning documentation, with a focus on type plans.

\begin{tabular}{|c|c|c|}
\hline \multirow{6}{*}{ 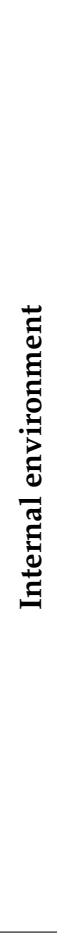 } & Strengths & Weaknesses \\
\hline & $\begin{array}{l}\text { Flexibility and alternative implementations } \\
\text { of the water-related crisis plan }\end{array}$ & $\begin{array}{l}\text { Ambiguous competences, especially on the } \\
\text { strategic level of regional management } \\
\text { (regional president-crisis measures from } \\
\text { the national level) }\end{array}$ \\
\hline & $\begin{array}{l}\text { Preparation of individual type plans up to } \\
\text { the level of concrete water-related crises }\end{array}$ & $\begin{array}{l}\text { Low engagement of management with } \\
\text { respect to the process of preparing crisis } \\
\text { plans (low knowledge of the links and } \\
\text { connections between individual parts of the } \\
\text { planning documentation focusing on water) }\end{array}$ \\
\hline & $\begin{array}{c}\text { Setup of a systemic hierarchical approach } \\
\text { on the town/regional/government levels } \\
\text { for handling crises }\end{array}$ & $\begin{array}{l}\text { Direct link between crisis management, } \\
\text { consisting of elected officials, to political } \\
\text { parties and special interests in society }\end{array}$ \\
\hline & $\begin{array}{l}\text { An ethical approach as a foundation for } \\
\text { correct behavior is always part of the plans } \\
\text { and the decision processes of management }\end{array}$ & $\begin{array}{l}\text { High demands on solutions in areas with } \\
\text { high concentrations of } \\
\text { inhabitants-municipal } \\
\text { agglomerations-and the need of ensuring a } \\
\text { timely and effective reaction in stationary } \\
\text { medical and social facilities }\end{array}$ \\
\hline & $\begin{array}{l}\text { Risk analysis carried out by a team of } \\
\text { experts, generally recognized and accepted }\end{array}$ & $\begin{array}{c}\text { Lack of information transfer and processing } \\
\text { of planning documentation on the } \\
\text { municipal level }\end{array}$ \\
\hline \multirow{6}{*}{ 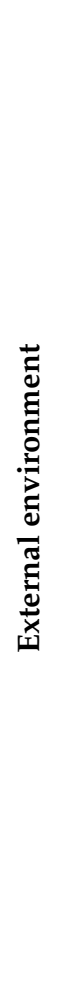 } & Opportunities & Threats \\
\hline & $\begin{array}{l}\text { Use of experience from previous crises in } \\
\text { the Czech Republic-notably floods }\end{array}$ & $\begin{array}{l}\text { Incorrect generalization of approaches } \\
\text { within crisis management and difficulty of } \\
\text { forecasting the occurrence of a large-scale } \\
\text { water-related crisis sufficiently in advance }\end{array}$ \\
\hline & $\begin{array}{l}\text { The specified resources intended for } \\
\text { handling catastrophes in crisis plans are } \\
\text { gradually purchased under the auspices of } \\
\text { the State Material Reserve Management }\end{array}$ & $\begin{array}{l}\text { Lack of experience of crisis management } \\
\text { and the population in general with } \\
\text { extensive interruptions of drinking } \\
\text { water supply }\end{array}$ \\
\hline & $\begin{array}{l}\text { Implementation of training with a focus on } \\
\text { the correct handling of and communication } \\
\text { during water-related crises on the } \\
\text { government, regional and municipal levels }\end{array}$ & $\begin{array}{c}\text { Difficulty of coordinating a large number of } \\
\text { different entities participating in the crisis } \\
\text { and its management }\end{array}$ \\
\hline & $\begin{array}{c}\text { Timely preparation and implementation of } \\
\text { preventive anti-flood measures and } \\
\text { measures for emergency supply of } \\
\text { drinking water }\end{array}$ & $\begin{array}{c}\text { Water-related crises may lead to secondary } \\
\text { societal impacts (interruption of power } \\
\text { supply, traffic restrictions, disruptions of } \\
\text { internal security, disruption of water } \\
\text { treatment plants, epidemiological } \\
\text { complications, etc.) }\end{array}$ \\
\hline & $\begin{array}{l}\text { Increase the international exchange of } \\
\text { experience in the area of catastrophe } \\
\text { management for water-related crises, } \\
\text { opportunities for cross-border and } \\
\text { internal collaboration }\end{array}$ & $\begin{array}{l}\text { Lack of focus on water-related crisis } \\
\text { management at the expense of other } \\
\text { catastrophes (COVID-19, migration) }\end{array}$ \\
\hline
\end{tabular}




\subsection{Calculation of SWOT Analysis}

After listing the strengths, weaknesses, opportunities and threats, each item was assessed individually. Based on the carried-out interpretation, a corresponding significance and value was assigned to the investigated area, leading to the creation of a comprehensive image. For strengths and opportunities, we used the positive scale of 1 to 5 , where 5 represented highest satisfaction and 1 lowest satisfaction. For weaknesses and threats, a negative scale of -1 (representing the smallest dissatisfaction) to -5 (representing the greatest dissatisfaction) was used instead. The assessment was performed on the basis of a multicriteria decision that is based on the selection or classification of values of one variation of the specified criteria. For the assessment of the individual characteristics of the SWOT analysis, the criteria of the social impact, impact on the health and lives of the population, economic regression, impact on the environment and restriction of transportation were specified. The multicriteria assessment was performed by a group of experts from the Regional Council of the South Bohemian Region-Crisis Management Department, Fire Rescue Service of the Czech Republic-Civil Protection Department, Police of the Czech Republic, Emergency Medical Services of the South Bohemian Region, Army of the Czech Republic, Czech Hydrometeorological Institute, Povodí Vltavy and VSB-Technical University of Ostrava.

The pair comparison method was used to determine the relative importance of the parameters of the strengths and weaknesses, opportunities and threats. A weight factor was calculated for each item, and this captured the importance of individual items in the given category. The greater the weight, the greater the importance of the item within its category, and vice-versa. The sum of the weights in each category was always 1 . The weight coefficients were obtained by comparing the individual criteria to each other. From each pair, the more important criterion with respect to the given problem was selected. The Fuller Triangle method was used to make the comparisons. The scores and weights were then multiplied with each other. The results in each category are summed up, after which the internal components (strengths and weaknesses) are summed up, while the external components (opportunities and threats) are summed up separately. These two results are then deducted from each other, resulting in the final value of the SWOT analysis $[35,36]$. The aforementioned calculation for the SWOT analysis of preparedness for water-related crises in the planning documentation focusing on type plans is presented in Tables 3 and 4 .

Table 3. Calculation for the SWOT analysis of preparedness for water-related critical situations in planning documentation with a focus on type plans.

\begin{tabular}{|c|c|c|c|c|}
\hline \multirow{14}{*}{ 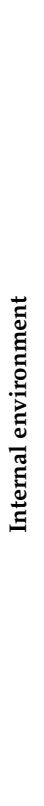 } & Strengths & $\begin{array}{l}\text { Weight } \\
\text { Factor }\end{array}$ & Score & $\begin{array}{l}\text { Criterion } \\
\text { Strength }\end{array}$ \\
\hline & S.1 Flexibility and alternative implementations of the water-related crisis plan & 0.27 & 4 & 1.07 \\
\hline & S.2 Preparation of individual type plans up to the level of concrete water-related crises & 0.33 & 5 & 1.67 \\
\hline & S.3 Setup of a systemic hierarchical approach on the town/regional/government levels for handling crises & 0.13 & 3 & 0.40 \\
\hline & $\begin{array}{l}\text { S.4 An ethical approach as a foundation for correct behavior is always part of the plans and the decision } \\
\text { processes of management }\end{array}$ & 0.07 & 2 & 0.13 \\
\hline & S.5 Risk analysis carried out by a team of experts, generally recognized and accepted & 0.20 & 3 & 0.60 \\
\hline & Sum for this component & & & 3.87 \\
\hline & Weaknesses & & & \\
\hline & $\begin{array}{l}\text { W.1 Ambiguous competences, especially on the strategic level of regional management (regional } \\
\text { president-crisis measures from the national level) }\end{array}$ & 0.13 & -2 & -0.27 \\
\hline & $\begin{array}{l}\text { W.2 Low engagement of management with respect to the process of preparing crisis plans (low knowledge of } \\
\text { the links and connections between individual parts of the planning documentation focusing on water) }\end{array}$ & 0.27 & -3 & -0.80 \\
\hline & $\begin{array}{l}\text { W.3 Direct link between crisis management, consisting of elected officials, to political parties and special } \\
\text { interests in society }\end{array}$ & 0.07 & -1 & -0.07 \\
\hline & $\begin{array}{l}\text { W.4 High demands on solutions in areas with high concentrations of inhabitants-municipal } \\
\text { agglomerations-and the need of ensuring a timely and effective reaction in stationary medical and } \\
\text { social facilities }\end{array}$ & 0.33 & -4 & -1.33 \\
\hline & W.5 Lack of information transfer and processing of planning documentation on the municipal level & 0.20 & -3 & -0.60 \\
\hline & Sum for this component & & & -3.07 \\
\hline
\end{tabular}


Table 3. Cont.

\begin{tabular}{|c|c|c|c|c|}
\hline \multirow{15}{*}{ 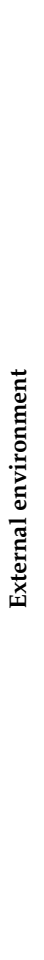 } & Strengths & $\begin{array}{l}\text { Weight } \\
\text { Factor }\end{array}$ & Score & $\begin{array}{l}\text { Criterion } \\
\text { Strength }\end{array}$ \\
\hline & Opportunities & & & \\
\hline & O.1 Use of experience from previous crises in the Czech Republic-notably floods & 0.27 & 4 & 1.07 \\
\hline & $\begin{array}{l}\text { O.2 The specified resources intended for handling catastrophes in crisis plans are gradually purchased under } \\
\text { the auspices of the State Material Reserve Management }\end{array}$ & 0.07 & 1 & 0.07 \\
\hline & $\begin{array}{l}\text { O.3 Implementation of training with a focus on the correct handling of and communication during } \\
\text { water-related crises on the government, regional and municipal levels }\end{array}$ & 0.20 & 3 & 0.60 \\
\hline & $\begin{array}{l}\text { O.4 Timely preparation and implementation of preventive anti-flood measures and measures for emergency } \\
\text { supply of drinking water }\end{array}$ & 0.33 & 5 & 1.67 \\
\hline & $\begin{array}{l}\text { O.5 Increase the international exchange of experience in the area of catastrophe management for } \\
\text { water-related crises, opportunities for cross-border and internal collaboration }\end{array}$ & 0.13 & 3 & 0.40 \\
\hline & Sum for this component & & & 3.80 \\
\hline & Threats & & & \\
\hline & $\begin{array}{l}\text { T.1 Incorrect generalization of approaches within crisis management and difficulty of forecasting the } \\
\text { occurrence of a large-scale water-related crisis sufficiently in advance }\end{array}$ & 0.13 & -3 & -0.40 \\
\hline & $\begin{array}{l}\text { T.2 Lack of experience of crisis management and the population in general with extensive interruptions of } \\
\text { drinking water supply }\end{array}$ & 0.27 & -4 & -1.07 \\
\hline & $\begin{array}{l}\text { T.3 Difficulty of coordinating a large number of different entities participating in the crisis and } \\
\text { its management }\end{array}$ & 0.07 & -1 & -0.07 \\
\hline & $\begin{array}{l}\text { T.4 Water-related crises may lead to secondary societal impacts (interruption of power supply, traffic } \\
\text { restrictions, disruptions of internal security, disruption of water treatment plants, epidemiological } \\
\text { complications etc.) }\end{array}$ & 0.33 & -5 & -1.67 \\
\hline & $\begin{array}{l}\text { T.5 Lack of focus on water-related crisis management at the expense of other catastrophes } \\
\text { (COVID-19, migration) }\end{array}$ & 0.20 & -2 & -0.40 \\
\hline & Sum for this component & & & -3.60 \\
\hline
\end{tabular}

Source: own research.

Table 4. Resulting values of the SWOT analysis.

\begin{tabular}{cc}
\hline Internal environment $(\mathrm{S}+\mathrm{W})$ & 0.80 \\
\hline External environment $(\mathrm{O}+\mathrm{T})$ & 0.20 \\
\hline Total (difference) & +0.60 \\
\hline Positive environment $(\mathrm{S}+\mathrm{O})$ & 7.67 \\
\hline Negative environment $(\mathrm{W}+\mathrm{T})$ & -6.67 \\
\hline Total (difference) & +1.00 \\
\hline
\end{tabular}

Source: own research.

\subsection{Assessment of SWOT Analysis}

The first step in the assessment of the SWOT analysis was to perform an evaluation based on multi-criteria decision-making carried out by a specialized group. This was followed by a calculation of the value of the weight criterion using Fuller's triangle, where the expert group compared the significance/priority of the individual elements of the SWOT analysis. A subsequent product of the identified values was then used to determine the strength of each criterion. All the data are provided in Table 3. An overview is provided by the sums for individual components of the SWOT areas, which are compared against each other in Table 4.

The resulting values of the SWOT analysis show that water-related crises for which a type plan has been prepared within crisis management based on a risk analysis received a slightly positive score- - a value of +0.60 . The factors arising from the internal environment are stronger than those arising from the external environment; that being said, the resulting score difference of 0.60 can also be considered very small. It is clear that it remains necessary to support and expand on the strengths, such as the preparation of detailed type plans covering specific water-related crises. Furthermore, the analysis also suggests that it would be helpful to take a closer look at problematic areas, notably the preparedness of all societal tools and solutions used for locations with high concentrations of inhabitants, municipal 
agglomerations and the need to implement timely and correct reactions in stationary medical and social facilities.

From another perspective, a comparison between the positive $(\mathrm{S}+\mathrm{O})$ and negative $(\mathrm{W}+\mathrm{T})$ environments was carried out. Here it is clear that the more dominant environment is the positive one, with a value of 7.67 compared to -6.67 . The resulting difference is +1.00 , indicating that the positive environment is dominant.

The final values also indicate that the system for handling water-related crises in the Czech Republic for which a type plan has been prepared based on risk analysis within crisis management is mildly positive. Further improvements are possible by reinforcing the system's strengths and minimizing its weaknesses in a way which makes use of available opportunities.

\section{Discussion}

The SWOT analysis methodology allows us to create a matrix summarizing the strengths, weaknesses, opportunities and threats and to evaluate these aspects. One advantage of this procedure is that it is possible to search for links between the identified items, and these links can then be used in the management strategies for the risks arising from the weaknesses and threats. The achieved results of the SWOT analysis indicate a small advantage of the positive approach and environment.

On the basis of the performed investigation, it can be said that planning documentation for managing water-related crises has been prepared in the Czech Republic. The individual plans contain selected measures that react to possible crisis scenarios. The possible impacts on society in the Czech Republic are reflected in the plans. The necessity of supporting the strengths and opportunities is evident from the performed SWOT analysis. The foundation is the analysis of the risks that ensue from this study and that are also one of the assessed characteristics of the strengths. When preparing the multicriteria analysis, which formed the basis of the creation of the score, attention was drawn to the imprecise resolution of the individual crisis situations and their considerable overlap. This applied to the examined crises of:

- floods,

- flash floods,

- excessive precipitation.

From the perspective of Opportunities, an emphasis was placed on the use of experience from the resolution of previous crises in the Czech Republic. The performed assessment was the source material for the update and innovation of the approach of the crisis management bodies on the level of the state administration and local governments. Another characteristic that was assessed is the implementation of exercises with a focus on solution possibilities and proper communication during water-related crises. The crisis plans were updated following the extreme floods in the Czech Republic in 1997 and 2002. Subsequently, however, a social position began to predominate that there is sufficient experience with floods and preventive flood measures were adopted and it is not necessary to spend much time and effort on this area. There is an exception, with regard to changes in climate conditions, to the approach to the preparation of the possible crisis situationlarge-scale disruptions of the supply of drinking water. In recent years, attention has been focused during exercises on the issue of a nuclear accident and the long-term interruption of the power supply.

When evaluating the Weaknesses, there is evidently a higher assessment of the characteristic of the higher demands on the solution:

- in areas with a high concentration of living persons (city agglomerations),

- the need for a timely and substantive reaction in health and social facilities of a stationary type.

The large-scale organization of crisis measures in sites with a high concentration of persons and health and social facilities is highly demanding and complicated for all 
types of events. Thus, it is important for the authorities and population on a communal level to have sufficient information on the planned measures and to also contribute to the acceptance of the preventative measures.

The results of the SWOT analysis for the area of Threats show the highest score for the characteristic of the threat of secondary impacts for crisis situations, e.g., the interruption of the power supply, traffic restrictions, disruptions of internal security, disruption of water treatment plants, epidemiological complications, etc. The minimization of the possibility of domino effects is a basic goal of crisis management and must also be resolved during water-related crises.

Safety is one of the basic characteristics of quality of life, for individuals as well as society as a whole. It is clear that society has a collective as well as individual dimension. The article focuses predominantly on the collective sphere of safety and the assessment of societal preparedness and resilience to water-related crises in the Czech Republic. However, the individual dimension of safety must also be taken into account. It is crucial to allow citizens to access information about possible risks and threats [38,39], and it is also important to ensure that the appropriate government bodies actively disseminate this information.

The society's preparedness for crises associated with a lack of drinking water or floods is based on two basic dimensions. On one hand, these are measures implemented by crisis management bodies and the resources and know-how available to the emergency system and its components. The second dimension consists of the education of the populace, whereas people know the principles on how to act in the event of such emergencies and can react in a timely and appropriate way. Collective and individual preparedness are prerequisites for the successful handling of crises and for minimizing death, property damage and damage to the environment.

The society's resistance to water-related crises is part of the wider concept of the society's safety and quality of life. Within this concept, it is necessary to distinguish between problems that are specifically related to safety-the protection of lives and healthor whether they are rather related to ensuring satisfactory living conditions, within the wider scope of human security. In some cases-notably, in well-developed countries-the impact may be primarily attributed to the latter, i.e., to maintaining a certain quality of life.

Safety can never be guaranteed completely and perfectly, and this naturally also applies to water-related crises. Aiming for complete safety and imagining that one can completely eliminate or prevent serious threats is dangerous and incorrect. The notion of societal vulnerability may be used to describe the level of safety of a society; this maps, categorizes and measures the amount of vulnerability.

The results of the presented study provide a new perspective on a case study covering the preparedness and resilience of society to water-related crises in the Czech Republic.

With the use of the SWOT analysis, it was shown that water-related crises for which a type plan has been prepared as part of the crisis planning on the basis of a risk analysis point to a slightly positive score - a value of +0.60 . The identified positives and negatives, and also the identified vulnerabilities, are the best ways to identify safety policy priorities. It is clear that the handling of water-related crises needs to be carried out via the implementation of preventive as well as reactive tools. Safety problems in general, and hence also waterrelated crises, cannot be handled exclusively via safety measures. Measures represent only concrete reactions to specific threats, but do not usually tackle the core (source) of the threat. Aside from strengthening safety capabilities, it is necessary to create a safe space and in general a safe environment by, e.g., proper zoning, landscape protection, and the protection of river basins.

\section{Conclusions}

This assessment of societal readiness and resilience to water-related situations in the Czech Republic focuses on an interdisciplinary approach in the Czech Republic for solving this problem. The goal of the article is to evaluate and characterize the preparedness for handling water-related crises, which are covered by a type plan based on a risk analysis 
within the scope of crisis planning. The assessment is carried out via a case study in the Czech Republic and focuses notably on the viewpoint of prepared societal measures. The theoretical part of the article delimits and characterizes selected type plans that are part of crisis plans and are related to water. The practical part of the article focuses on an assessment of selected measures of type plans with a focus on water.

The analysis is carried out via a SWOT analysis, which is a universal analytical method used to understand and interpret strengths and weaknesses and to identify opportunities and threats. For the calculation of the weight factor of the SWOT analysis, an assessment was determined based on the multicriteria analysis that a group of selected experts performed on crisis management, planning and risk analysis. The pair comparison method was used to determine the relative importance of the parameters of the strengths and weaknesses, opportunities and threats. The Fuller Triangle method was chosen for the system used to make the comparisons of the individual criteria. The obtained information led to the results of the assessment of water-related crises which are covered by a type plan based on a risk analysis within the scope of crisis planning.

On the basis of the performed investigation, it can be said that planning documentation for managing water-related crises has been prepared in the Czech Republic. The individual plans contain selected measures that react to possible crisis scenarios. The possible impacts on society in the Czech Republic are reflected in the plans.

From the perspective of Opportunities, an emphasis was placed on the use of experience from the resolution of previous crises in the Czech Republic. Another characteristic that was assessed is the implementation of exercises with a focus on solution possibilities and proper communication during water-related crises. When evaluating the Weaknesses, there is evidently a higher assessment of the characteristic of the higher demands on the solution in areas with a high concentration of living persons (city agglomerations) and the need for a timely and substantive reaction in health and social facilities of a stationary type.

With the use of the SWOT analysis, it was shown that water-related crises for which a type plan has been prepared as part of the crisis planning on the basis of a risk analysis point to a slightly positive score - a value of +0.60 . The identified positives and negatives, and also the identified vulnerabilities, are the best ways to identify safety policy priorities. It is clear that the handling of water-related crises needs to be carried out via the implementation of preventive as well as reactive tools. Safety problems in general, and hence also waterrelated crises, cannot be handled exclusively via safety measures.

The uniqueness of the study consists of the issue of water management, which is thus reflected from a non-traditional perspective, being a contemporary model-the paradigm of the view on the preparedness of the planning documentation as one of the characteristics of societal resilience for water-related crises.

Author Contributions: Data curation, Š.K. (Štěpán Kavan), J.P.; Formal analysis, Š.K. (Štěpán Kavan), Š.K. (Šárka Kročová); Investigation, Š.K. (Štěpán Kavan), Š.K. (Šárka Kročová), J.P., Methodology, Š.K. (Štěpán Kavan); project administration, J.P.; Editing, Š.K. (Šárka Kročová). All authors have read and agreed to the published version of the manuscript.

Funding: This research was funded by the Ministry of the Interior of the Czech Republic Project No. VH20182020042 Population Protec-tion in a Spatial Planning and within Setting Technical Conditions for Building Engineering.

Institutional Review Board Statement: To exclude this statement - the study did not involve humans or animals. Not applicable.

Informed Consent Statement: Not applicable.

Data Availability Statement: Not applicable.

Conflicts of Interest: The authors declare no conflict of interest. 


\section{References}

1. Kročová, Š. Strategie Dodávek Pitné Vody; Sdružení požárního a bezpečnostního inženýrství: Ostrava-Poruba, Czech Republic, 2009; 158p, SPBI Spektrum 63, ISBN 978-80-7385-072-2.

2. Bozek, F.; Bozek, A.; Bumbova, A.; Bakos, E.; Dvorak, J. Classification of Ground Water Resources for Emergency Supply. World Academy of Science, Engineering and Technology. Int. J. Geol. Environ. Eng. 2012, 6, 728-731. Available online: http:/ / waset.org/publications/9966 (accessed on 21 November 2020).

3. Bozek, F.; Bumbova, A.; Bakos, E.; Bozek, A.; Dvorak, J. Semi-quantitative risk assessment of groundwater resources for emergency water supply. J. Risk Res. 2014, 18, 505-520. [CrossRef]

4. Bross, L.; Krause, S. Preventing Secondary Disasters through Providing Emergency Water Supply. In World Environmental and Water Resources Congress 2017; American Society of Civil Engineers: Reston, VA, USA, 2017; pp. 431-439. [CrossRef]

5. Bumbová, A.; Čáslavský, M.; Božek, F.; Dvořák, J. The Analysis of Hazard and Sensitivity of Potential Resource of Emergency Water Supply. World Acad. Sci. Eng. Technol. Int. J. Environ. Ecol. Eng. 2013, 7, 634-639. Available online: https://waset.org/ publications /16845/the-analysis-of-hazard-and-sensitivity-of-potential-resource-of-emergency-water-supply (accessed on 12 November 2020).

6. Loo, S.L.; Fane, A.G.; Krantz, W.B.; Lim, T.T. Emergency water supply: A review of potential technologies and selection criteria. Water Res. 2012, 46, 3125-3151. [CrossRef]

7. Word Health Organization. Water Safety Plans. Managing Drinking-Water Quality from Catchment to Consumer; WHO/SDE/WSH/ 05.06; Word Health Organization: Geneva, Switzerland, 2005.

8. Sayers, P.; Yuanyuan, L.; Galloway, G.; Penning-Rowsell, E.; Fuxin, S.; Kang, W.; Yiwei, C.; Le Quesne, T. Flood Risk Management: A Strategic Approach; Asian Development Bank: Paris, France, 2013; ISBN 978-92-3-001159-8.

9. Drotárová, J.; Vacková, M.; Mesároš, M. Voluntery Municipal Fire Brigades as a part of Crisis Management in the context of Flood Protection. In Proceedings of the SGEM 2019 Conference Proceedings (5.1. Ecology, Economics, Education and Legislation): Ecology and Environmental Protection, Sofia, Bulgaria, 28 June-7 July 2019; pp. 809-816. [CrossRef]

10. Esposito, G.; Parodi, A.; Lagasio, M.; Masi, R.; Nanni, G.; Russo, F.; Alfano, S.; Giannatiempo, G. Characterizing Consecutive Flooding Events after the 2017 Mt. Salto Wildfires (Southern Italy): Hazard and Emergency Management Implications. Water 2019, 11, 2663. [CrossRef]

11. Intrieri, E.; Dotta, G.; Fontanelli, K.; Bianchini, C.; Bardi, F.; Campatelli, F.; Casagli, N. Operational framework for flood risk communication. Int. J. Disaster Risk Reduct. 2020, 46, 101510. [CrossRef]

12. Pan, T.-Y.; Lin, H.-T.; Liao, H.-Y. A Data-Driven Probabilistic Rainfall-Inundation Model for Flash-Flood Warnings. Water 2019, 11, 2534. [CrossRef]

13. Yang, T.; Liu, W. A General Overview of the Risk-Reduction Strategies for Floods and Droughts. Sustainability 2020, $12,2687$. [CrossRef]

14. Akpoti, K.; Antwi, E.O.; Kabo-Bah, A.T. Impacts of Rainfall Variability, Land Use and Land Cover Change on Stream Flow of the Black Volta Basin, West Africa. Hydrology 2016, 3, 26. [CrossRef]

15. Tuladhar, D.; Dewan, A.; Kuhn, M.; J Corner, R. The Influence of Rainfall and Land Use/Land Cover Changes on River Discharge Variability in the Mountainous Catchment of the Bagmati River. Water 2019, 11, 2444. [CrossRef]

16. Morán-Tejeda, E.; Fassnacht, S.R.; Lorenzo-Lacruz, J.; López-Moreno, J.I.; García, C.; Alonso-González, E.; Collados-Lara, A.-J. Hydro-Meteorological Characterization of Major Floods in Spanish Mountain Rivers. Water 2019, 11, 2641. [CrossRef]

17. Müller, U. Implementation of the flood risk management directive in selected European countries. Int. J. Disaster Risk Sci. 2013, 4, 115-125. [CrossRef]

18. Molenveld, A.; van Buuren, A. Flood Risk and Resilience in the Netherlands: In Search of an Adaptive Governance Approach. Water 2019, 11, 2563. [CrossRef]

19. Mose Venezia. Per la Difesa di Venezia e Della Laguna Dalle Acque Alte; Consorzio Venezia Nuova: Venice, Italy, 2020. Available online: https: / / www.mosevenezia.eu/ (accessed on 2 November 2020).

20. FloodRe. Flood Re is Helping Insurers to Help Householders at Risk of Flooding; Flood Re Limited: London, UK, 2020. Available online: https:/ / www.floodre.co.uk/ (accessed on 9 November 2020).

21. Maléřová, L. Assessment of Safety Level Risk. In Crisis Management A Leadership Perspective; Nova Science Publishers. Inc.: New York, NY, USA, 2016; pp. 127-139. ISBN 978-1-63483-395-0.

22. Anttiroiko, A.-V. Successful government responses to the pandemic: Contextualizing national and urban responses to the COVID-19 outbreak in east and west. Int. J. E-Plan. Res. 2021, 10, 1-17. [CrossRef]

23. Moon, J.; Sasangohar, F.; Son, C.; Peres, S.C. Cognition in crisis management teams: An integrative analysis of definitions. Ergonomics 2020, 63, 1240-1256. [CrossRef]

24. Mcmaster, R.; Baber, C. Multi-agency operations: Cooperation during flooding. Appl. Ergon. 2012, 43, 38-47. [CrossRef]

25. Garschagen, M.; Sandholz, S. The role of minimum supply and social vulnerability assessment for governing critical infrastructure failure: Current gaps and future agenda. Nat. Hazards Earth Syst. Sci. 2018, 18, 1233-1246. [CrossRef]

26. Dušek, J. International Cooperation of Regional Authorities of the Czech Republic: History, Presence and Future. In Proceedings of the 18th International Colloquium on Regional Sciences, Masaryk University, Hustopece, Czech Republic, 17-19 June 2015; pp. 300-305. [CrossRef] 
27. Kováčová, L.; Vacková, M. Achieving of environmental safety through education of modern oriented society. In Proceedings of the 14th SGEM GeoConference on Ecology, Economics, Education and Legislation, Albena, Bulgaria, 17-26 June 2014; Volume 2, pp. 3-8. [CrossRef]

28. KAVAN, Š. Výsluhové nároky př́slušníků bezpečnostních sborů v České republice. In Proceedings of the International Conference Safe and Secure Society 2020, College of European and Regional Studies, Ceske Budejovice, Czech Republic, 14-15 October 2020; pp. 52-60. [CrossRef]

29. Usnesení Vlády ČR č. 369 ze dne 27. Dubna 2016 k Analýze Hrozeb pro Českou Republiku. 2020. Available online: https: / / apps.odok.cz / djv-agenda?date=2016-04-27 (accessed on 2 November 2020).

30. Ivančík, R. Quo Vadis európska obrana a bezpečnost'. Politické Vedy 2019, 22, 47-67. [CrossRef]

31. Pokorný, J.; Tomášková, M.; Balažiková, M. Study of changes for selected fire parameters at activation of devices for smoke and heat removal and at activation of fixed extinguishing device. MM (Mod. Mach.) Sci. J. 2015, 2015, 764-767. [CrossRef]

32. Lukáš, L. Vývoj Českého bezpečnostního pojmosloví. In Conference Proceedings of VII. Medzinárodnej Vedeckej Konferencie Bezpečné Slovensko a Eúropská únia; University of Security Management in Košice: Košice, Slovac Republic, 2013; ISBN 978-80-89282-88-3.

33. Svoboda, J.; Václavík, V.; Dvorský, T.; Klus, L. The design of flood protection in Kobeřice municipality. IOP Conf. Ser. Earth Environ. Sci. 2017, 92, 012062. [CrossRef]

34. Newton, P.; Bristoll, H.B.R. SWOT Analysis: Free eBook; Free Management Books: USA, 2013. Available online: http://www.freemanagement-ebooks.com/dldebk/dlst-swot.htm (accessed on 2 November 2020).

35. Fine, L.G. The SWOT Analysis: Using Your Strength to Overcome Weaknesses, Using Opportunities to Overcome Threats; Createspace Independent Publishing Platform: North Charleston, SC, USA, 2009; ISBN 1449546757.

36. Shewan, D. How to Do a SWOT Analysis for Your Small Business (with Examples). WordStream: Online Advertising Made Easy. 2018. Available online: https:/ / www.wordstream.com/blog/ws/2017/12/20/swot-analysis (accessed on 8 November 2020).

37. Sarsby, A. SWOT Analysis: A Guide to Swot for Business Studies Students; Spectaris Ltd.: Stowmarket, UK, 2016 ; ISBN 0993250424.

38. Kročová, Š.; Kavan, Š. Cooperation in the Czech Republic border area on water management sustainability. Land Use Policy 2019, 86, 351-356. [CrossRef]

39. KAVAN, S. Selected social impacts and measures resulting from the Covid-19 epidemic in the Czech Republic on the specific example of the South Bohemian Region. Health Social Care Community 2021. [CrossRef] [PubMed] 